\title{
Natural heavy metal and metalloid concentrations in sediments of the Minho River estuary (Portugal): baseline values for environmental studies
}

\author{
M. Mil-Homens • A. M. Costa • S. Fonseca • \\ M. A. Trancoso • C. Lopes • R. Serrano • R. Sousa
}

Received: 26 June 2012 / Accepted: 5 November 2012

(C) Springer Science+Business Media Dordrecht 2012

\begin{abstract}
Forty-nine surface sediment samples from the Minho estuary sector between Tui and Caminha were analyzed for grain-size contents, $\mathrm{Al}, \mathrm{As}, \mathrm{Cr}, \mathrm{Cu}$, $\mathrm{Hg}, \mathrm{Li}, \mathrm{Pb}, \mathrm{Sn}$, and $\mathrm{Zn}$ concentrations. Selected heavy
\end{abstract}

\footnotetext{
M. Mil-Homens $(\bowtie) \cdot$ C. Lopes

Instituto Português do Mar e da Atmosfera, I.P.,

Av. Brasília,

1449-006 Lisbon, Portugal

e-mail: mario.milhomens@ipma.pt

M. Mil-Homens $\cdot$ A. M. Costa $\cdot$ C. Lopes

Unidade de Geologia Marinha,

Laboratório Nacional de Energia e Geologia, I.P.,

Estrada da Portela, Apartado 7586,

2721-866 Alfragide, Portugal
}

\section{A. M. Costa}

Arqueociências, IGESPAR, I.P. and LARC, CIBIO/InBIO,

Rua da Bica do Marquês. No. 2,

1300-087 Lisbon, Portugal

S. Fonseca $\cdot$ R. Serrano

Laboratório de Referência do Ambiente, Núcleo

Operacional de Química Inorgânica,

Agência Portuguesa do Ambiente, I.P.,

Rua da Murgueira, 9-9A, Zambujal, Apartado 7585,

2611-865 Amadora, Portugal

M. A. Trancoso $\cdot$ R. Sousa

Laboratório de Biocombustíveis e Ambiente,

Laboratório Nacional de Energia e Geologia, I.P.,

Azinhaga dos Lameiros,

1649-038 Lisbon, Portugal metal ( $\mathrm{Cu}, \mathrm{Cr}, \mathrm{Hg}$, and $\mathrm{Zn}$ ) and metalloid (As and $\mathrm{Sn}$ ) distributions were normalized against $\mathrm{Al}$ and $\mathrm{Li}$ with the main goal of compensating for natural grain-size variability and to separate natural from anthropogenic contributions, by using a combination of normalization techniques (definition of regional geochemical baselines (RGB) and determination of enrichment factors $(\mathrm{EF})$ ). Lead did not reveal a significant relationship with $\mathrm{Al}$ and Li. Aluminum explained more variance than $\mathrm{Li}$ for $\mathrm{As}, \mathrm{Cu}, \mathrm{Hg}$, and $\mathrm{Zn}$. Assuming the general non-impacted metal character of the Minho River estuary sediments, RGBs are defined for differentiating between natural and anthropogenic contributions. Based on RGB defined for each heavy metal/ metalloid, the degree of enrichment is estimated through the determination of EF. Despite the relatively low total heavy metal and metalloid concentrations, the defined RGB identifies a set of samples characterized by presenting $\mathrm{As}, \mathrm{Cu}, \mathrm{Cr}, \mathrm{Hg}$, and $\mathrm{Zn}$ enrichments relatively to expected natural levels. Mercury is the element showing the highest level of enrichment relative to the baseline values being spread through all the study area. Tin present enrichments relatively to $\mathrm{Al}$ and or $\mathrm{Li}$ always lower than 1.5 suggesting natural contributions.

Keywords Minho estuary · Sediments · Heavy metal and metalloid concentrations · Environmental assessment $\cdot$ Regional geochemical baselines . Enrichment factors 